\title{
Budget cuts cause upheavals in earthquake research
}

\section{David Dickson describes how a sociologist's misbehaviour has led to a major gap in efforts to restrict the damage caused by earthquakes}

Two years ago, Los Angeles City Council member Howard Jarvis-later to achieve fame as author of California's tax-cutting Proposition 13-led a successful campaign on behalf of the city's apartment owners to prevent signs being posted on private buildings liable to collapse during an earthquake. Some months later, sociologists found in a survey that over $90 \%$ of the inhabitants of the city, where more than 20,000 buildings are considered to be inadequately protected against earthquakes, thought that the posting of such signs would be a good idea.

Professor Ralph Turner of the University of California in Los Angeles, who heads the research team which conducted the survey as part of a wider project, claims that if the results had been known previously, the city council might have acted differently, and that they illustrate the type of role that the social sciences could play in mitigating the damage caused by earthquakes.

Yet, as the result of congressional actions last summer, National Science Foundation funds for social science research in this area have been savagely cut back. The foundation has been forced to reject all proposals for new projects so that existing ones can be completed. And even in the next fiscal year, funds for such policy research, according to the budget request now being submitted to Congress, will only be one-fifth of the amount originally requested for 1979 .

Two years ago, the picture looked very different. With growing concern about a (supposedly) imminent earthquake in California, President Ford requested in his last budget proposal that spending on earthquake hazard reduction programmes at the NSF be

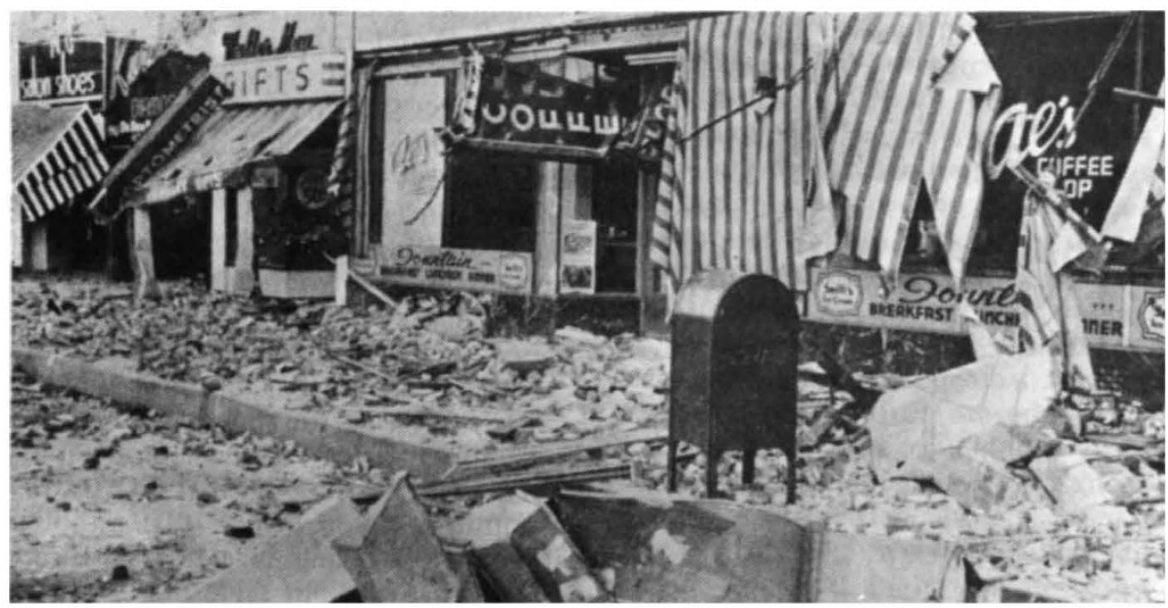

After an earthquake: devastation on the sidewalk of a southern California town. increased from \$12 million in 1977 to $\$ 32$ million in 1979 (with an even larger increase at the US geological survey). Last year President Carter responded to legislation passed by Congress by setting out a national earthquakes hazards reduction programme. This stated that earthquakes posed "perhaps the greatest single-event natural hazards faced by the nation" (estimates put the property at risk at $\$ 2,300,000$ million), and assigned the NSF to carry out basic and applied research on earthquake engineering and policy.

Then along came Senator William Proxmire. During hearings on the NSF budget, it emerged that a professor of sociology at the university of Colorado, Dr J. Eugene Haas, who had received NSF contracts for more than $\$ 500,000$ to carry out research into the socioeconomic and political consequences of earthquake prediction, had used the money for, among other things, taking his girl friend on a trip to Honolulu, Tokyo and Hong Kong.

Congress is seldom kind to social scientists, and this misbehaviour, for which Professor Haas was subsequently dismissed from the university, was sufficient for the House Appropriations Committee to reduce the NSF's request for earthquake hazard research from $\$ 26.4$ million to $\$ 17.4$ million. Within this total, the amount to be allocated to social science policy research was reduced from $\$ 4.8$ million to $\$ 800,000$, the remainder being divided between siting and engineering design studies.

NSF officials were accused by the appropriations committee of mismanaging the funds awarded to Professor Haas. They were also stung by the claim that similar work was being carried out in other agencies, since they say these agencies turn to the foundation for their research support. Nevertheless the result has been that the NSF has had to reject all new proposals for research on the policy aspects of earthquake mitigation.

These projects involved assessing the reaction on social and political institutions of information about earthquakes, as well as of the earthquakes themselves. "It is not just a question of needing more research. This is a subject that has never been adequately developed because there has never been a long-term commitment to provide support", Dr Robert Olsen, a social scientist of the Seismic Safety Commission in Sacramento, California, who has chaired a panel on the potential contribution of the social sciences, said last week.

"Many of our problems in reducing earthquake damage relate to legal and institutional considerations that affect the use of technical knowledge and its translation into public policy. The budget reductions mean that the lack of sufficient high quality people willing to undertake such projects is likely to remain."

Dr Olsen's brother, and associate professor in political science at the University of Redlands outside Los Angeles, is one of those who have proposed a major study to the NSF for which he has been told there is no money. The project would involve a two-year investigation in the San Bernardino area of how seismic safety issues are perceived by decision makers. "We shall be putting the proposal in again, and if it flies, it flies. Otherwise this is the last shot. Personally, the lack of money is driving me back into more traditional areas of social science."

Some feel that, despite the tough budget year, the NSF could be more aggressive in its approach to Congress. At present the foundation is requesting a level of funding for 1980 little higher than that to which it was reduced in the current year. "We will do what we can to get this raised, but it would have been easier if they had asked for a little more", the aide to one Californian congressman said last week.

Others feel it may take a major earthquake before research money starts flowing in. According to Dr Carl Kisslinger, president of the American Geophysical Union, the mayor of Pinotep Nacional in Mexico has claimed that public reaction to an earthquake forecast by US scientists did more damage to the economy of his town than the 7.5 magnitude shock that hit the area last August. 